\title{
Corrigendum
}

\section{Engraftment associated hypophosphatemia - the role of cytokine release and steep leukocyte rise post stem cell transplantation}

P Raanani, I Levi, F Holzman, I Grotto, F Brok-Simoni, A Avigdor, J Davidson, O Shpilberg and I Ben-Bassat

Bone Marrow Transplantation 2001; 27: 311-317

Since publication of the above issue, the author has noticed an error in Figure 5. The values on the 'Y-axis' were incorrect. Please find to follow a corrected version.

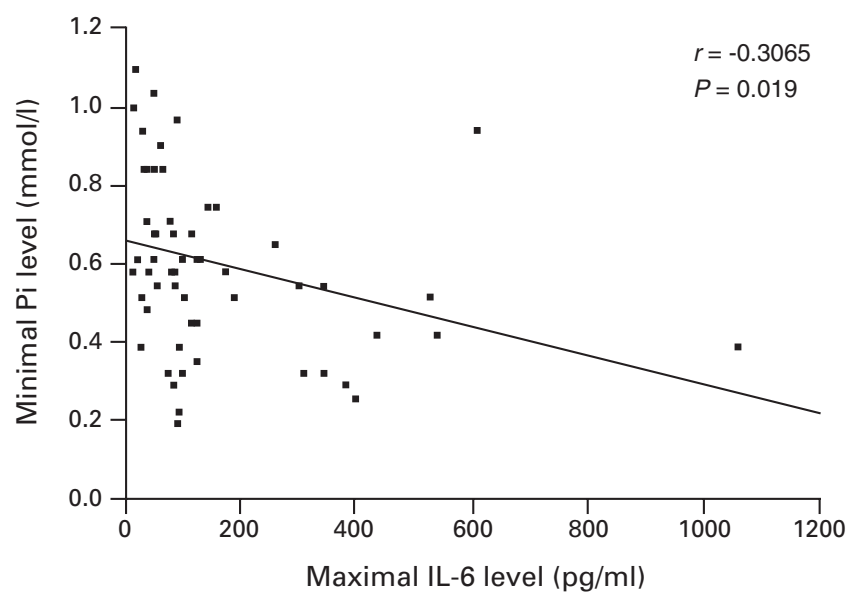

Figure 5 Correlation between maximal IL-6 level and minimal Pi level. Values shown are in $\mathrm{pg} / \mathrm{ml}$ for IL-6 and in $\mathrm{mmol} / \mathrm{l}$ for $\mathrm{Pi}(n=58)$. 